\title{
Organizational Commitment as Mediation Variable Influence of Work Motivation, Leadership Style and Learning Organization to the Employees Performance (Studies at PT. Pelabuhan Indonesia IV (Limited) Branch Bitung)
}

\author{
Irvan Trang ${ }^{1}$, Armanu $^{2}$, Achmad Sudiro $^{3}$, Noermijati ${ }^{4}$ \\ ${ }^{I}$ (Economics Faculty, University of Sam Ratulangi, Indonesia) \\ ${ }^{2,3,4}$ (Economics and Business Faculty, University of Brawijaya, Indonesia)
}

\begin{abstract}
The research is based on the phenomenon of an International-Scale State-Owned Enterprises by implementing Modern HRM operating at the city of Bitung, North Sulawesi province. It is interesting to study how far the work motivation, leadership style of learning organization as fundamental variables and organizational commitment as mediation in influencing the employees performance of this company. Overall, the goal of development in the field of HR in companies today is the achievement of the quality of human resources and the people of Indonesia are developed in an atmosphere of peace and happiness. The importance of improving the quality of human resources in the company because the environment is constantly changing. In the management and development of human resources, a philosophy is needed that not only recognizes the importance of employees as individuals but also as an important element of a company. In the current era of globalization, the management company must pay attention and improve employee performance and company performance. The fact is that organizations are generally confronted with a problem concerning its human resources, especially the attitudes and behavior of employees at work. This can be realized through the provision of work motivation, the appropriate leadership style in an organization, the creation of a learning organization continuously so as to improve organizational commitment and higher employee performance. The purpose of this study is to identify and investigate the effect of work motivation, leadership style and learning organization on employee performance mediated by organizational commitment at PT. Pelabuhan Indonesia IV (Limited) Branch Bitung. The research population is all employees at PT. Pelabuhan Indonesia IV (Limited) Branch Bitung, including organic employees in each staff division and operational of PT. Pelabuhan Indonesia IV (Limited) Branch Bitung as many as 92 employees, not including the leaders. In this study, it was decided that the entire population were sampled by using the census method (saturated sample). This study uses quantitative analysis method of data analysis tools of PLS (Partial Least Square). The results stated that work motivation, learning organization has a positive and significant influence on employee performance through the mediating variable of organizational commitment, while the style of leadership does not have a significant influence on employee performance through the mediating variable of organizational commitment. Furthermore, organizational commitment has a positive and significant effect on the performance of employees of PT. Pelabuhan Indonesia IV (Limited) Branch Bitung.
\end{abstract}

Keywords: Work Motivation, leadership style, learning organization, organizational commitment, employee performance

\section{Introduction}

Looking back from the year 1959 until now there are many studies that reveal about motivation (Herzberg, 1959), leadership (Bass, 1990), learning organization (Senge, 1990), organizational commitment (Mowday, Steers and Porter, 1979) and Performance (Cash and Fischer, 1987). Since the 1960's, the organizational commitment has become to the concept and measurement of the patent literature in the state of North America. Typical measurement of organizational commitment as a force in the know and identify the behavior of people in an organization (Mowday, Steers and Porter, 1979). In 1984, Allen and Meyer aims to make the conceptual development dimension of organizational commitment by taking into consideration the affective commitment and continuants. In 1991, they added a third component, it's normative commitment (Allen and Meyer, 1991). Affective commitment as an emotional attachment through, identification with involvement in the organization. Normative commitment as an employee feeling in their obligation to remain with the organization. Continuant commitment interpreted as a commitment based on the costs associated with employees when they leave the organization (Allen and Meyer, 1991). To foster the employee commitment and performance would require employee's work motivation related to the behavior of a leader who emphasizes continuous learning process, thus identifying the goal this time is to look at organizational commitment as 
mediation variables influencing the work motivation, leadership style and learning organization on employee performance.

We all know that the goal of human resource development in the field today is the achievement of the quality of human resources and the people of Indonesia are developed in an atmosphere of peace and happiness. The importance of improving the quality of human resources as the environment is constantly changing. In human resource management, a philosophy required that not only recognizes the importance of employees as individuals but also as an important element of an organization.

Armstrong (2003) states that the existing human resources within the company needed to be managed professionally in order to realize a balance between the needs of employees with the demands and capabilities of the company. This balance is the key for a company to develop productively and reasonably. In the current era of globalization, the management company must pay attention and improve employee performance and company performance, Suprihanto et al., (2002:3). This opinion does not correspond to what happens in PT. Pelabuhan Indonesia IV (Limited) Branch Bitung, where in recent years the performance of the employees are declining, this is due to the polemic and multi interpretation of Decree No. 17/2008 regarding the legal certainty and business certainty for port and shipping enterprises, thus decrease the motivation for employees in improving their performance. Then the style of leadership in the enterprise were transactional and authoritarian that did not involve employees in decision making, the emergence of new competitors in the port and shipping businesses, as well as the declining performance of the employee because many employees are looking for work and additional projects outside the company. Employees' high motivation to their work affects their performance towards the organization. Work motivation is a force both from inside and outside that drives one to achieve certain goals that have been defined previously (Herzberg, 1996).

Furthermore, in addition to motivation, the role of a leader is crucial in enhancing the performance of employees. As noted by Rauch and Behling (Yukl, 2002) that leadership is a process of influencing the activities of an organized group toward the achievement of the goals set. In addition to employee motivation, leadership style a leader in the PT. Pelabuhan Indonesia IV (Limited) Branch Bitung, it is no less important is the role of the learning organization in an effort to improve employee performance. It is like that presented by Senge (1993) learning organization is an organization that consists of people continually enhancing its capacity to realize the desirable employee's performance.

In Indonesia, there has been much research on motivation, leadership, commitment and performance, but still lack researcher that touch specifically on the topic of learning organization using indicators of personal mastery, mental models, shared vision, team learning, systems thinking and dialogue, it is as proposed by Senge (1990). Furthermore, no studies using organizational commitment as mediating the relationship between work motivation, and leadership style and learning organization towards employee performance. Research conducted by Mo (2011) analyzes the intrinsic and extrinsic motivation on the performance of students of accounting programs. The results of the empirical approach follow the development of the conceptual framework from Baron and Keny (1986) and the mediating effects of test / data collection of the school of accounting. The results indicate that the partial mediating effect on the variables of intrinsic motivation and extrinsic motivation. Broadly speaking, that intrinsic motivation plays an important role in improving the performance of students of accounting programs. Research conducted by Kim (2011) which examined the effects of ethical leadership in performance improvement of a middle level hotel manager, which in turn affects the behavior of the administrator, which in turn can affect the performance of the hotel. This study suggests that the ethical leadership of middle executive is positively related to performance. Middle managers job satisfaction is positively related to organizational commitment. Furthermore, Aragon (2007) in his study discusses the role of traditional leadership and learning organization towards innovation and performance. The results found that leadership style had no direct effect towards the innovation and performance and learning organization does not directly impact on innovation and performance but through organizational commitment as a mediating variable.

Studies conducted by Feng (2010) confirms and analyze the performance of the faculty lecturer at the University and identified four variables namely organizational commitment, job stress, mental health and motivation to achieve success in motivation. The results found that organizational commitment significantly affect the performance, job stress has no effect on performance, mental health also had no effect on performance and motivation affect the performance of the lecturer. Furthermore Bilik (2008) in his research showing result that organizational commitment, work motivation and leadership styles have a positive impact on employee performance.

Problem In this study is: 1) is the motivation given by the company mediated by organizational commitment will influential to improve the performance of employees of PT. Pelabuhan Indonesia IV (Limited) Branch Bitung? 2) Is a compliance leadership style within the company to be mediated by organizational commitment will influential to improve the performance of employees of PT. Pelabuhan Indonesia IV (Limited) Branch Bitung? 3) Is the provision of more learning opportunities by learning organization to be mediated by 
organizational commitment will influential to improve the performance of employees of PT. Pelabuhan Indonesia IV (Limited) Branch Bitung? 4) Is the organizational commitment of employees will influential to improve the performance of employees of PT. Pelabuhan Indonesia IV (Limited) Branch Bitung?

This study's goal is 1) to determine and identify the influence of work motivation mediated by organizational commitment to improving the performance of employees of PT. Pelabuhan Indonesia IV (Limited) Branch Bitung, 2) to determine and identify the influence of leadership styles that are mediated by organizational commitment to improving the performance of employees of PT. Pelabuhan Indonesia IV (Limited) Branch Bitung, 3) To know and identify the influence of a learning organization mediated by organizational commitment to improve the performance of employees of PT. Pelabuhan Indonesia IV (Limited) Branch Bitung, 4) To determine and identify the influence of organizational commitment to improving employee performance (PT. Port Indonesia IV (Limited) Branch Bitung.

\section{This research benefits:}

Theoretical benefits of this research are expected to have contributed to the development of science, especially the enrichment of theory implementation especially about theories of motivation, leadership theory, organizational behavior theory, the theory of a learning organization that integrated towards the theory of organizational commitment and employee performance theory. Practical benefits are 1) To provide a solution to overcome the problems that arise in organizations of PT. Pelabuhan Indonesia IV (Limited) Branch Bitung particularly with regard to motivation, leadership styles, learning organization, organizational commitment and employee performance, 2) The results of this study can be used as a conceptual contribution to the PT. Pelabuhan Indonesia IV (Limited) Branch Bitung leadership decisions in order to be able to provide motivation to employees, to create a leadership style that favor by employees, providing the opportunity for organizations to learn continuously toward better direction through a high organizational commitment so as to improve the overall performance of employees at PT. Pelabuhan Indonesia IV (Limited) Branch Bitung, 3) As a reference for future research in the field of management, particularly in the development of human resources and organizational behavior.

\section{Work Motivation}

\section{Fundamental Theories}

In carrying out the work, it is necessary to have work motivation for employee, because work motivation can provide the energy that drives all the existed potential, creating a high and noble desires and can improve morale and excitement of working together. In addition to motivation, leadership is also important. Thus, if the employee has a high motivation and good leadership then the employees will show their loyalty and commitment to the organization who hired him. Some sense of motivation given by experts, among others according to Herzberg (Moon, 1993) that work motivation is an urge that drives someone to do some activities as well as a boost in a person to do a job.

Furthermore, Herzberg (Moon, 1993) and Nawawi (2001:359) put forward that there are two types of motivation, namely intrinsic and extrinsic motivation.

a. Intrinsic motivation is the driving force that comes from working within the workers as individuals, in the form of awareness about the importance or meaning of the work he is performing. For example, someone who is doing the work, the main goal is that the work can be completed properly and correct, so that they have pride in themselves.

b. Extrinsic motivation is the driving force that comes from outside the employee as an individual worker, in the form of a condition that required him to carry out the work to its full potential, e.g. highly dedicated in working for wages or high salaries, ranks or position of honor or have great power, praise, punishment and others.

\section{Leadership Style}

Leadership is defined as an effort to influence followers through the communication process to achieve certain goals. According to Robbins (1991) leadership is the ability to influence a group of members to work toward goals and objectives. Adler (1997) clarifies that "leadership includes the ability to influence and inspire ways of thinking, acting, and behaving of its members". One of the available leadership style is transformational leadership, which by Burns (1978, Yukl, 1998:296) defined as "a process of mutual increase among leaders and followers to the higher level of morality and motivation". Bass (1994) also stated that leadership style includes three common conditions, namely transformational leadership style, transactional leadership style and laissez faire leadership style or condition without leadership. Barbuto (2005) declared the emergence of transformational leadership style and transactional leadership style is the result of more than a hundred years assessment, so it can be said that the two leadership styles are able to represent many kinds of leadership styles 
available all this time. Conceptually, transformational leadership style is defined Bass and Avolio (2003) as the ability of leaders to change the work environment, work motivation, and work patterns, and work values perceived by subordinates so that they are better able to optimize performance to achieve organizational goals. While transactional leadership style is one leadership style that basically emphasizes transaction between leaders and subordinates. Transactional leadership allows leaders to motivate and influence subordinates by exchanging rewards with certain performance. That is, in a transaction, a subordinate were promised to be given rewards when subordinates are able to complete their duties in accordance with the collaborative agreements, Mustopadidjaja (2008:38). The reason for this push Bass and Avolio (2003) to define transactional leadership as a form of relationship that exchange office or a specific task if the subordinate is able to complete the task properly. Thus, transactional leadership emphasizes the exchange of valuable relationships to biological and psychological needs in accordance with the contract they had agreed together.

\section{Learning Organization}

In the beginning, learning organization has been discussed in some literature around 1920s. However, since 1980 only a few organizations realize the importance of learning organization in improving organizational commitment. Learning organization that is much discussed since the late 1970s with contributors such as Argyris and Schon (1974), Senge (1990) and Pedler et al., (1991), often conceptualized with reference to the definition of Pedler et al., (1991) about learning company as an organization that facilitates the learning of its entire organization and continuously transforms itself. Learning organizational is an organization that has people constantly enhancing its capacity to realize a commitment and desired performance. Where new thinking patterns were expansively grown and where collective aspiration is set and its members continually learning to see the whole together (Senge, 1993). According to Senge (1990) there are five skills (skills) needed to create and optimize an organization's ability in the learning process. The five skills is very important to be owned in improving organizational commitment, namely personal mastery (personal skills), mental models, shared vision, learning team and systems thinking.

\section{Organizational Commitment}

High organizational commitment is needed in an organization, because the creation of a high commitment will affect professional work situations. According to Mowday, Steers, and Porter (1979), organizational commitment as the relative strength of an individual's identification with and involvement in organization. Aldag and Reschke (1997) define organizational commitment as the strength of an individual's identification with, involvement in, and attachment to the organization. According to Allen and Meyer cited by Satta (2000) that organizational commitment is a psychological bond that is based on three forms, namely: affective, normative, and continuance commitment (The Three-Component Model of Organizational Commitment). According to Meyer et al., (1993) organizational commitment consists of three dimensions. First, employees with strong affective commitment (recognition and attachment to the organization) to work continuously due to they want to do it. Second, employees who have a relationship with an organization that is based on continuance commitment (aware of the costs associated if they leaving the organization) is expected to remain in the organization because they need to do it. Third, employees with normative commitment (feelings towards guarantees the right of social stress) felt that they should remain (ought to) with the organization.

\section{Employee Performance}

Performance is often referred to as performance or result (Cash and Fischer, 1987) which means that what has been produced by the individual employee. Further according to Schermerhorn, Hunt and Osbom, (1991) the performance of the employees as the quality and quantity of the achievement of tasks, whether perpetrated by individuals, groups and companies. The degree to which a person in doing his work called the level of performance (Vroom, 1964). Cash and Fischer, (1987 in Heidjrachman Ranupandoyo and Suad Husnan, 2000) states that the level of performance and performance measurement of an employee can be seen through the achievements of several factors, namely:

1. Quality of work

Assessment of the employee's ability to complete the job compared to the set targets.

2. Quantity of work

Assessment of the ability of employees to complete tasks accurately according to the quality of the work planned.

3. Timeliness

Assessment of the ability of employees to complete tasks and work closely in the time according to the time been given and planned. 


\section{Conceptual Framework For Research}

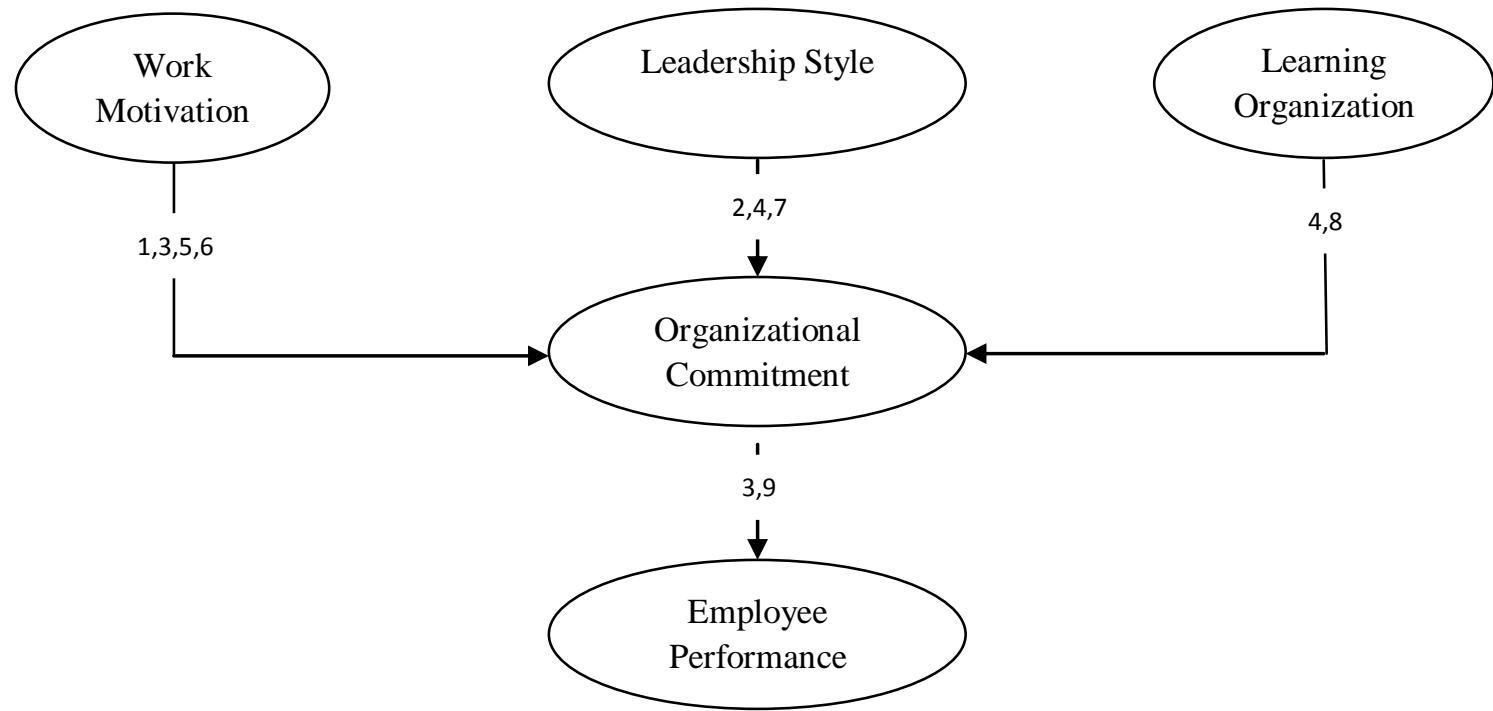

\section{Remarks:}
1. Mo (2011)
6. Rifa'i (2004)
2. $\operatorname{Kim}(2011)$
7. Brymer (2011)
3. Feng (2010)
8. Moralles (2007)
4. Aragon (2007)
9. Pozo 2007)

5. Bilik (2008)

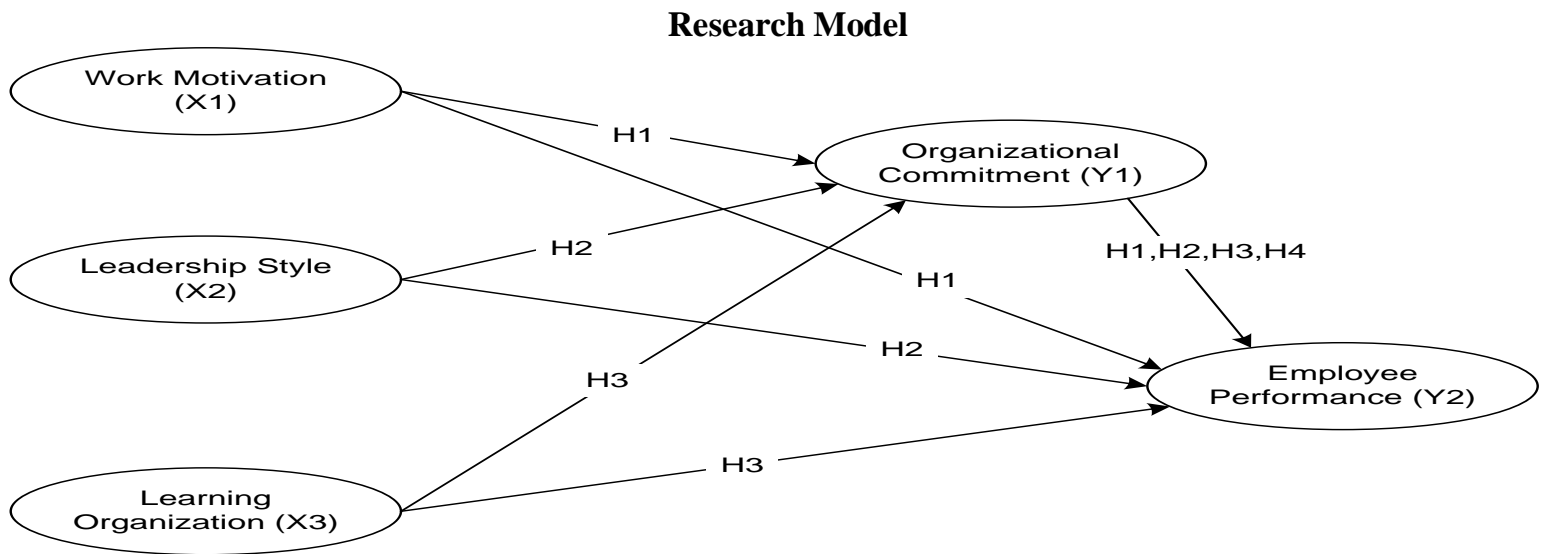

\section{Research Hypothesis}

$\mathbf{H}_{1}$. The existence of motivation to be mediated by organizational commitment influential to improve the performance of employees of PT. Pelabuhan Indonesia IV (Limited) Branch Bitung.

$\mathbf{H}_{2}$. The leadership style within the company mediated by organizational commitment influential to improve the performance of employees of PT. Pelabuhan Indonesia IV (Limited) Branch Bitung.

$\mathbf{H}_{3}$. The number of learning opportunities provided by the learning organization mediated by organizational commitment influential to improve the performance of employees of PT. Pelabuhan Indonesia IV (Limited) Branch Bitung.

$\mathbf{H}_{4}$. Organizational commitment of employees influential to improve the performance of employees of PT. Pelabuhan Indonesia IV (Limited) Branch Bitung.

\section{Operational Definition of Variables}

The independent variable in this study is motivation, leadership style and organizational learning and organizational commitment is a mediating variable while the dependent variable is the performance of the employees. 
Work motivation is an urge in a person to do a job, (Herzberg, in Moon, 1993). Work motivation in this study were employees response towards an urge contained in an individual as a result of the influence comes from within themselves and from outside that leading, directing, and organizing behavior to perform tasks. Indicators in this study are intrinsic and extrinsic motivation.

Leadership style is the style of a leader to influence and mobilize subordinates so that they can work to its full potential (Robbins, 1991). Leadership styles defined in this study is the ability of a leader to influence a group of employees to work toward the goals and objectives of an organization. Indicators in this study are the leadership style of transformational and transactional leadership styles.

Learning organization is an organization that has people that constantly enhancing its capacity to make a commitment that really wanted by the organization (Senge, 1990). Learning organization in this research is an organization that facilitates the learning of all employees and the continuously transforms itself. Indicators in this study are personal mastery, mental models, shared vision, team learning, systems thinking and dialogue.

Organizational commitment is the desire of the employee to keep working and comply with the rules of the organization, and refused offers to work elsewhere (Allen and Meyer, 1990). Organizational commitment in this study is a binder between the individual and an institution or with a project activity or more generally with the idea of an organization as a whole. Indicators in this study were affective commitment, continuant and normative commitment continuants.

Employee performance are the employees' appraisal of the final results of the work activities that can be measured by the ability to work function and motivation which were the intervention, competency, proficiency and skills in performing the tasks (Cash and Fischer, 1987). Performance of the employees in this research is the quality, quantity and timeliness of achievement tasks, whether perpetrated by individuals, groups and companies. Indicators in this study are the quantity of work, quality of work and punctuality.

Measurement of research variables using Likert Scale with intervals of study ranging from a score of 1 to a score of 5 . Score $1=$ Strongly Disagree, Score $2=$ Disagree, Score $3=$ Neutral, Score $4=$ Agree and Score 5 $=$ Strongly Agree.

\section{Research Methods}

The research was conducted at PT. Pelabuhan Indonesia IV (Limited) Branch Bitung, North Sulawesi province. The approach used in this study is a quantitative approach. The population in this study was all employees at PT. Pelabuhan Indonesia IV (Limited) Branch Bitung, including organic employees in each division staff and operational of PT. Pelabuhan Indonesia IV (Limited) Branch Bitung totaled as many as 92 employees, not including the leaders.

In this study, since the population was only 92 employees, it was decided that the entire population in PT. Pelabuhan Indonesia IV (Limited) Branch Bitung were sampled; the census (saturated sample) amounted to 92 employees. The design of the questionnaire set of indicators reflected the latent variables and items in the form of a statement prepared statement closed with a Likert Scale, validity and reliability tests are also performed. To test the proposed model, the statistical analysis techniques of PLS (Partial Least Square) were used (Solimun, 2008).

\section{RESULT}

Analysis of PLS (Partial Least Square)

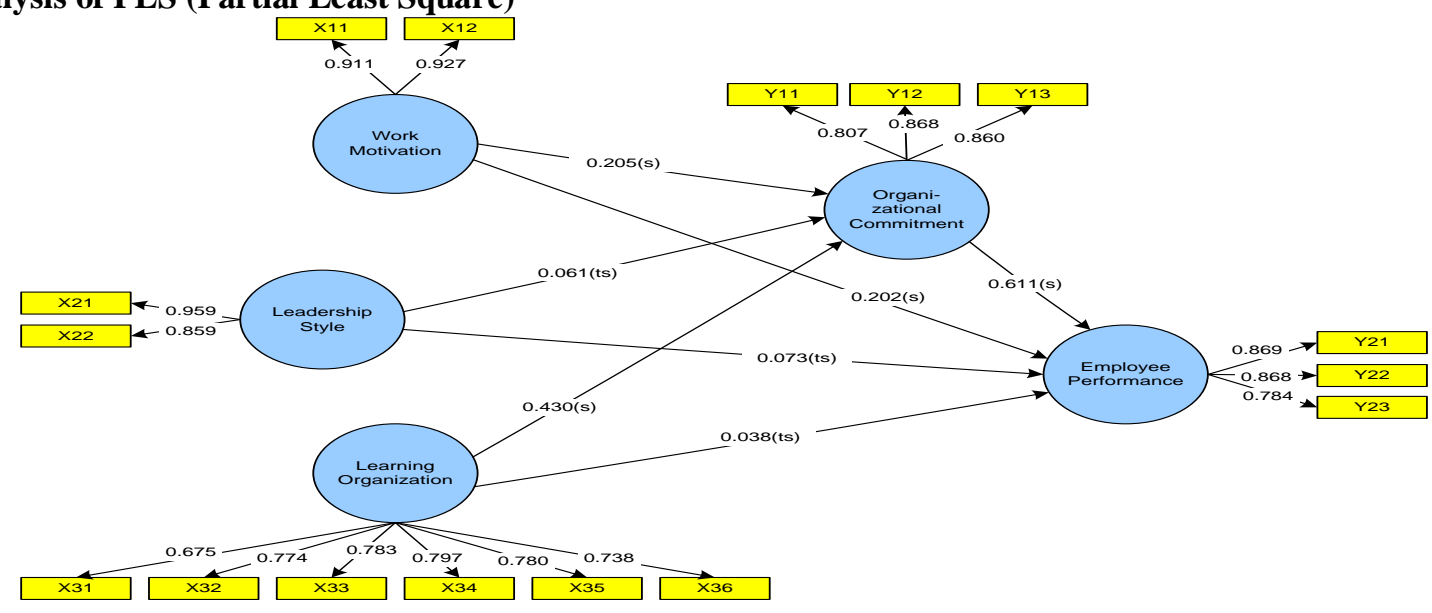


Organizational Commitment As Mediation Variable Influence Of Work Motivation, Leadership Style

Hypothetical Test

\begin{tabular}{|c|c|c|c|c|}
\hline Exogeneous Variable & Endogeneous Variable & $\begin{array}{c}\text { Path of } \\
\text { Coefficient }\end{array}$ & p-value & Remarks \\
\hline Work Motivation & $\begin{array}{c}\text { Organizational } \\
\text { Commitment }\end{array}$ & 0.205 & 0.022 & Significant \\
\hline Leadership style & $\begin{array}{c}\text { Organizational } \\
\text { Commitment }\end{array}$ & 0.061 & 0.427 & Not Significant \\
\hline Learning Organization & $\begin{array}{c}\text { Organizational } \\
\text { Commitment }\end{array}$ & 0.430 & 0.000 & Significant \\
\hline Work Motivation & Employee Performance & 0.202 & 0.010 & Significant \\
\hline Leadership style & Employee Performance & 0.073 & 0.371 & Not Significant \\
\hline Learning Organization & Employee Performance & 0.038 & 0.643 & Not Significant \\
\hline $\begin{array}{c}\text { Organizational } \\
\text { Commitment }\end{array}$ & Employee Performance & 0.611 & 0.000 & Not Significant \\
\hline
\end{tabular}

Result of Indirect Influence Test

\begin{tabular}{|c|c|c|c|c|}
\hline Indirect Influence & \multicolumn{2}{|c|}{ Direct Influence Coefficient } & $\begin{array}{c}\text { Indirect } \\
\text { Influence } \\
\text { Coefficient }\end{array}$ & Remarks \\
\hline $\mathrm{X} 1 \rightarrow \mathrm{Y} 1 \rightarrow \mathrm{Y} 2$ & $\mathrm{X} 1 \rightarrow \mathrm{Y} 1=0.205$ & $\mathrm{Y} 1 \rightarrow \mathrm{Y} 2=0.611$ & 0.125 & Significant \\
\hline $\mathrm{X} 2 \rightarrow \mathrm{Y} 1 \rightarrow \mathrm{Y} 2$ & $\mathrm{X} 2 \rightarrow \mathrm{Y} 1=0.061$ & $\mathrm{Y} 1 \rightarrow \mathrm{Y} 2=0.611$ & 0.037 & Not Significant \\
\hline $\mathrm{X} 3 \rightarrow \mathrm{Y} 1 \rightarrow \mathrm{Y} 2$ & $\mathrm{X} 3 \rightarrow \mathrm{Y} 1=0.430$ & $\mathrm{Y} 1 \rightarrow \mathrm{Y} 2=0.611$ & 0.263 & Significant \\
\hline
\end{tabular}

Mediation Test using Sobell Test Approach

Result Analysis of Organizational Commitment mediation for Work motivation influence towards Employee Performance

\begin{tabular}{|c|c|c|c|l|}
\hline \multicolumn{5}{|l|}{ Model Without Mediation Variable } \\
\hline Relation & Coefficient & $\mathbf{t}_{\text {statistic }}$ & P-value & Remarks \\
\hline $\mathrm{X} 1 \rightarrow \mathrm{Y} 2$ & 0.329 & 3.799 & 0.000 & Significant \\
\hline Model With Mediation Variable \\
\hline Relation & Coefficient & $\mathbf{t}_{\text {statistic }}$ & P-value & Remarks \\
\hline $\mathrm{X} 1 \rightarrow \mathrm{Y} 2$ & 0.202 & 2.561 & 0.010 & Significant \\
\hline $\mathrm{X} 1 \rightarrow \mathrm{Y} 1$ & 0.205 & 2.292 & 0.022 & Significant \\
\hline $\mathrm{Y} 1 \rightarrow \mathrm{Y} 2$ & 0.611 & 6.146 & 0.000 & Significant \\
\hline $\mathrm{X} 1 \rightarrow \mathrm{Y} 1 \rightarrow \mathrm{Y} 2$ & 0.125 & 2.158 & 0.031 & Significant \\
\hline
\end{tabular}

Result Analysis of Organizational Commitment mediation for Leadership style influence towards Employee Performance

\begin{tabular}{|c|c|c|c|c|}
\hline \multicolumn{5}{|c|}{ Model Without Mediation Variable } \\
\hline Relation & Coefficient & $\mathbf{t}_{\text {statistic }}$ & P-value & Remarks \\
\hline $\mathrm{X} 2 \rightarrow \mathrm{Y} 2$ & -0.024 & 0.213 & 0.813 & Not Significant \\
\hline \multicolumn{5}{|c|}{ Model With Mediation Variable } \\
\hline Relation & Coefficient & 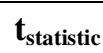 & P-value & Remarks \\
\hline $\mathrm{X} 2 \rightarrow \mathrm{Y} 2$ & 0.073 & 0.895 & 0.371 & Not Significant \\
\hline $\mathrm{X} 2 \rightarrow \mathrm{Y} 1$ & 0.061 & 0.795 & 0.427 & Not Significant \\
\hline $\mathrm{Y} 1 \rightarrow \mathrm{Y} 2$ & 0.611 & 6.146 & 0.000 & Significant \\
\hline $\mathrm{X} 2 \rightarrow \mathrm{Y} 1 \rightarrow \mathrm{Y} 2$ & 0.047 & 0.786 & 0.432 & Not Significant \\
\hline
\end{tabular}


Organizational Commitment As Mediation Variable Influence Of Work Motivation, Leadership Style

Result Analysis of Organizational Commitment mediation for Learning organization influence towar
Employee Performance
\begin{tabular}{|c|c|c|c|c|}
\hline Model Without Mediation Variable \\
\hline Relation & Coefficient & $\mathbf{t}_{\text {statistic }}$ & P-value & Remarks \\
\hline $\mathrm{X} 3 \rightarrow \mathrm{Y} 2$ & 0.306 & 3.804 & 0.000 & Significant \\
\hline Model With Mediation Variable & Coefficient & $\mathbf{t}_{\text {statistic }}$ & P-value & Remarks \\
\hline Relation & 0.038 & 0.463 & 0.643 & Not Significant \\
\hline $\mathrm{X} 3 \rightarrow \mathrm{Y} 2$ & 0.430 & 5.235 & 0.000 & Significant \\
\hline $\mathrm{X} 3 \rightarrow \mathrm{Y} 1$ & 0.611 & 6.146 & 0.000 & Significant \\
\hline $\mathrm{Y} 1 \rightarrow \mathrm{Y} 2$ & 0.263 & 3.996 & 0.000 & Significant \\
\hline $\mathrm{X} 3 \rightarrow \mathrm{Y} 1 \rightarrow \mathrm{Y} 2$ & & & &
\end{tabular}

Hypothesis 1 is accepted, that the work motivation mediated by the organizational commitment influential to improve the employees performance at PT Pelabuhan Indonesia IV (Limited) Branch Bitung.

Hypothesis $\mathbf{2}$ is rejected or unaccepted, which states that the compatibility of the existing leadership style within the company mediated by organizational commitment influential to improve the employees performance at PT Pelabuhan Indonesia IV (Limited) Branch Bitung, but this does not correspond to the results obtained, where the influence of leadership style on Employee Performance through Organizational Commitment were insignificant.

Hypothesis 3 received, the number of learning opportunities that are given to the learning organization mediated by organizational commitment influential to improve the performance of employees of PT. Pelabuhan Indonesia IV (Limited) Branch Bitung.

Hypothesis 4 received, that the organizational commitment of employees influential to improve the performance of employees of PT. Pelabuhan Indonesia IV (Limited) Branch Bitung.

\section{Results Discussion}

Influence of the Work Motivation towards Employee Performance through Organizational Commitment

The test results shows that the direct effect of work motivation on employee performance, and the mediating effect of organizational commitment on the influence of motivation on employee performance, both equally significant and direct influence coefficient slightly greater than the indirect effect of the mediation results. It can be concluded that organizational commitment is mediated in part (partial mediation) on the effect of work motivation on employee performance. Meaning, the work motivation given by PT. Pelabuhan Indonesia IV (Limited) Branch Bitung to its current employees both intrinsic and extrinsic motivation includes the award by the company, the opportunity for employee achievement, career opportunities, salary given by the company, job security, a comfortable work environment can already be quite and in accordance with the expectations of employees which can improve employee performance. This can be seen clearly based on of the overall average value of the work motivation variable at moderate categories.

Highest factor loaded on work motivation is extrinsic motivation indicators. It can be explained that employees assess the main motivation is extrinsic motivation in which extrinsic motivation from the management was needed by employees of PT. Pelabuhan Indonesia IV (Presero) Branch Bitung, whether it is salary given by the company to employees, job security guarantees given by the company to the employees, comfortable work environment conditions and policies given by the management company. While the lowest loading factor is intrinsic motivation indicator, which means that there are many employees who are less seen the roles, responsibilities and functions as well as the opportunity for a career. Thus, it is better if the management always pays attention to and improves the delivery of work motivation i.e. more specific intrinsic motivation for the employees so that it can improve the performance of employees of PT. Pelabuhan Indonesia IV (Limited) Branch Bitung.

Furthermore, the existing work motivation with the support and high commitment of organizational mediation of employee of PT. Pelabuhan Indonesia IV (Limited) Branch Bitung were also include employee commitment to duty, the employee's commitment to spend the rest of their career with the company, employees' commitment to work until retirement it will further improve their performance towards the achievement of corporate goals. It is based on the highest loading factor on organizational commitment is continuants commitment indicator, where employees are willing to works though relatively small salary and pension is the crucial attraction for the employee to continue to work to improve their performance.

Employee performance in this case is the employees mastering the job as a whole, the results obtained are as expected by the company, employees have the speed in the work, the results of work performed have 
meet the expectation, increase in employees' quality standards and completion of a given job on time. Thus, it helps if all of it can be maintained and enhanced so that the employees and the company will be able to improve organizational commitment and employee performance PT. Pelabuhan Indonesia IV (Limited) Branch Bitung overall.

These results are consistent with research conducted by Mo (2011) and Feng (2011). The results of their study showed that the model of relationship between motivation to performance is positive and significant. Furthermore, the results of this study as well as to strengthen and confirm the theory proposed by Herzberg (in Moon, 1993) that work motivation is an urge that drives someone to do some activity as well as a boost in oneself to do a job in achieving the desired goals.

Then the theory advanced by Robbins (1998) that organizational commitment is the degree to which an employee were in favor to a particular organization and its goals and intend to maintain membership in the organization. Higher organizational commitment means the alignment to the organization is also high. Commitment as a predictor of a person's performance is a better predictor and globally and survived in the organization as a whole rather than just job satisfaction. One might be dissatisfied with a certain job and consider it as a temporary condition, but the dissatisfaction with the organization as a whole and dissatisfaction when it spreads to the organization, could encourage people to consider themselves to resign. It is also consistent with the theory proposed by Cash and Fischer (1987) that the employee's performance is what has been produced by individuals either work quality, quantity and timeliness of work.

\section{Influence of leadership style on Employee Performance through Organizational Commitment}

The results of the analysis showed there was no influence of organizational commitment mediating to the leadership style influence on employee performance. It means that the leadership style practiced in PT. Pelabuhan Indonesia IV (Limited) Branch Bitung this time less influential in improving the performance of employees, it is based on the overall average value of the variable leadership style which is at medium category, meaning that many of the employees who are less responsive in viewing the current leadership style, which is meanly the unclear leadership style, the continuously changing style of leadership depending on the mood and currently many employees of PT. Pelabuhan Indonesia IV (Limited) Branch Bitung have lack of trust to their leaders.

Based on the highest factor loading on the style of leadership is transformational leadership style indicator, meaning that employees are assessing the leadership styles primarily on transformational leadership style. Employees are more likely to see transformational leadership style of the leader who gives guidance, encouragement and cooperation in completing the work. While the lowest loading factors contained in the transactional leadership style, which means many employees see the leaders were lack of provide direction and reward.

The leadership style is currently less influential in fostering organizational commitment of employees of PT. Pelabuhan Indonesia IV (Limited) Branch Bitung as a whole which includes the company's values that were developed in accordance with the job, employees are willing to run errands though relatively small salary, a pension is an attraction for employees to continue working and the employees did not want to work anywhere else, so that organizational commitment would eventually affect employee performance improvement. Based on the existing results it is clear that organizational commitment cannot mediate the influence of leadership styles that exist in the company to increase employee performance. If this is ignored constantly by the management of PT. Pelabuhan Indonesia IV (Limited) Branch Bitung, it will automatically have an impact on overall employee performance.

Thus the unclear leadership style could not be implemented and maintained at PT. Pelabuhan Indonesia IV (Limited) Branch Bitung. Based on observations in the field, a lot of employees expecting the participatory leadership where the leadership made a persuasive approach, creating a harmonious cooperation, foster loyalty and participation of subordinates. Furthermore, based on the field observation, it is also appropriate if the management of PT. Pelabuhan Indonesia IV (Limited) Branch Bitung apply the authoritarian leadership style. To increase organizational commitment of employees to the organization will needed a leader who has the legal power and authority which the absolute majority remain at the top leader. It is based also on the history of the PT. Pelabuhan Indonesia IV (Limited) Branch Bitung which undergone several transformations to SOEs (State Owned Enterprises) in which every government organization is always synonymous with rules and bureaucracy, thus autocratic leadership style would be more appropriate when applied to government organizations such as the PT. Pelabuhan Indonesia IV (Limited) Branch Bitung.

Bottom line, if the management of PT. Pelabuhan Indonesia IV (Limited) Branch Bitung retains leadership style patterns that are not obvious as it is currently, and then automatically the management of the company will encounter many obstacles in the future. It would also be contrary to the Vision and Mission of PT. Pelabuhan Indonesia IV (Limited) Branch Bitung, which is to became the international standard port services of an independent, healthy and ensure the sustainability of the national system of transparency. Next, develop a 
business that can provide optimum benefits for shareholders, accelerate regional development Pelindo IV, providing quality services, on time with decent rates, and develop competence, commitment and improving human welfare.

These results are not in accordance with the study by Kim (2011) and Brymer (2011). The results showed that the relationship between model of leadership style to performance is positive and significant. The results of this study do not support the research of Aragon (2007) in which leadership style does not directly affect employee innovation and performance but is mediated by organizational commitment, whereas in this study the leadership style had no effect on the performance of employees through organizational commitment as a mediating variable.

Furthermore, the results of this study confirm the theory once proposed by Robbins (1991) that the style of leadership is the ability to influence a group of members to work towards goals and objectives, but the reality is contrary to what is encountered in the field at the PT. Pelabuhan Indonesia IV (Limited) Branch Bitung, where the current leadership style has no effect on the performance of employees of PT. Pelabuhan Indonesia IV (Limited) Branch Bitung through organizational commitment.

\section{Influence the Learning Organization for Employee Performance through Organizational Commitment}

The test results showed that there was only the influence of organizational commitment mediation to the effect of motivation on employee performance. Due to the organizational commitment mediation, the learning organization direct effect becomes insignificant (on the model before the mediation analysis, the direct impact of learning organization towards the performance of significant employee were visible, and on the model after analysis mediation, there was a visible direct impact of learning organization to the insignificant employee), then the organizational commitment has the nature of full mediation towards the effect of learning organization to the employee performance. This can be seen clearly on the basis of the overall average value on learning organization variables at high categories.

Highest loading factor on the learning organization is a team learning indicator. It can be explained that employees assess learning organization primarily seen from the team learning. Thus, the team learning from the management company is highly needed by PT. Pelabuhan Indonesia IV (Presero) Branch Bitung's employee, both a medium to support the working group communication, the organizational structure to facilitate the employees to share knowledge and an opportunity to learn a relevant field of study. While the loading factor of the lowest was on personal mastery indicators, it can be explained that there are many employees who lack of self-introspection and the ability to see the internal condition of the company.

Overall the learning opportunities provided by PT. Pelabuhan Indonesia IV (Limited) Branch Bitung to employees currently covers both personal mastery (self-introspection to enhance the ability of individuals, continually improve performance from day to day, being able to see the condition of internal company objectively), mental models (a commitment to share knowledge, togetherness in solving the problem), shared vision (able to see the vision and mission of the company, to develop the existing visions), team learning (work group communication, knowledge sharing, got the opportunity to learn), thinking system (employee aspirations forward, always doing improvements toward better condition) and dialogue (always communicates between colleagues) are able to increase overall employee performance. Thus, learning organization in PT. Pelabuhan Indonesia IV (Limited) Branch Bitung is now be said to be good and it's good if it will be retained in order to improve employee performance.

Furthermore, the existing learning organizations which is supported by high organizational commitment mediation of employees of PT. Pelabuhan Indonesia IV (Limited) Branch is also include a commitment to duty, commitment to spend the rest of his career with the company, commitment to work until retirement, all those will be more able to improve the performance of the employees towards the achievement of corporate goals. It is based on the highest loading factor to organizational commitment is the indicator of continuants commitment, where employees are willing to work though relatively small salary and pension is the main attraction for the employee to continue to work to improve their performance.

Employees performance is in this case are employees who control the work as a whole, the work has been obtained in accordance with the standards of the company, employees have the speed in the work, the results of work performed by qualified employees, an increase in employees' quality standards and punctuality of work completion, where it is based on variable loading factor, the highest indicator of employees performance is work quality. Thus, all these things should be maintained and improved by the employee and management of the company, whether it's a chance to learn given by the company to the employees and the support and mediation of organizational commitment of employees in the industry that will be able to improve the performance of employees of PT. Pelabuhan Indonesia IV (Limited) Branch Bitung as a whole.

These results are consistent with research conducted by Aragon (2007) and Moralles (2007). Where, the results of their study showed that the relationship model of Learning Organization has indirect effect on innovation and performance through organizational commitment as a mediating variable. 
Furthermore, the results of this study as well as to strengthen and confirm the theory proposed by Marquardt (1996) and Senge (1990) where the opinion that the main key strength of a learning organization is an organization that strives to improve its capacity to make changes in the organization by providing opportunities to its members to incorporate initiatives, creating free space for continuous learning. Those opportunity will accelerate learning organization to achieve the desired results through individual and group learning.

\section{Effect of Organizational Commitment on Employee Performance}

The results of the analysis of the influence of Organizational Commitment on Employee performance is positive where the Organizational Commitment affecting the Employee Performance. The path coefficient is positive indicating that the both influence is in the same direction. The higher Organizational Commitment, it will lead to the higher employee performance. Vice versa, the lower Organizational Commitment, it could lead the lower Employee Performance. This can be seen clearly on the basis of the overall average value of organizational commitment variables at high categories.

Highest loading factor on organizational commitment is a continuants commitment indicator, meaning that many employees assess organizational commitment primarily seen from continuants commitment. It can be explained that the continuant commitment of the employees of PT. Pelabuhan Indonesia IV (Presero) Branch Bitung currently includes the willingness to work though relatively small salary, retirement is the main attraction to continue working could be valued as good. Overall, that the existing organizational commitment to employees of PT. Pelabuhan Indonesia IV (Limited) Branch Bitung currently includes both affective commitment (including the growing values of the company at this time, the attention of the company, employees are happy to spend the rest of his career with the company), Continuant Commitment (employees willingly do the work even though his salary is relatively small, willingly transferred employees, retirement is an attraction for employees), Normative Commitment (Company becoming the workplace to employees until pensions, the company provides protection to the employees against all existing the risks) has already been able to increase overall employee performance. Thus, organizational commitment in PT. Pelabuhan Indonesia IV (Limited) Branch Bitung currently can be valued as good and it will be good if it will be retained in order to improve employee performance in the future.

Furthermore, organizational commitment has a mediating role in linking work motivation towards employee performance and learning organizational on employee performance while leadership styles on employee performance can be said that organizational commitment does not play a role in mediating the relationship. It is clear that organizational commitment is mediated in part (partial mediation) on the effect of work motivation on employee performance and organizational commitment is in complete mediation (full mediation) on the effect on learning organization towards employee performance. Thus, the higher the organizational commitment owned by the employees of PT. Pelabuhan Indonesia IV (Limited) Branch Bitung then certainly the employee performance will increase, both working quantity (mastery of jobs by the employee, the work the employee obtained, employees' pace of work), Work Quality (the quality of the employee's job, work tasks in accordance with the standards in the company, increasing employee job quality standards from day to day), as well as Timeliness (jobs and tasks assigned to employees by the company and the leader were finished on time). It is better if all these things can be maintained and enhanced so that the employees and the company will be able to improve the performance of employees of PT. Pelabuhan Indonesia IV (Limited) Branch Bitung as a whole.

These results are consistent with studies conducted by Feng (2010) and Bilik (2008). The results of their study stated that the model of the relationship of Organizational Commitment on Employee Performance is positive and significant.

Furthermore, the results of this study as well as to strengthen and confirm the theory advanced by Robbins (1998) that organizational commitment is the degree to which an employee were in favor of a particular organization and its goals and intend to maintain membership in the organization.

Then the theory proposed by Cash and Fischer (1987) that the employee's performance is what has been produced by individuals either work quality, quantity and timeliness of work.

Thus, of the four hypotheses exist, then there are three accepted hypothesis, the positive and significant, i.e. Work Motivation is affecting the Employee Performance through Organizational Commitment, and then the Learning Organization is affecting the Employee Performance through Organizational Commitment and Organizational Commitment affecting the Employee Performance. Meanwhile, there is a hypothesis that is rejected or not accepted, not positive and not significant, i.e. leadership style had no effect on Employee Performance through Organizational Commitment. 


\section{Research Findings}

1. Work motivation, learning organization affects the employee performance mediated by organizational commitment, whereas leadership style had no effect on the employee's performance mediated by organizational commitment.

2. Organizational commitment is mediated in part (partial mediation) on the influence of motivation on employee performance.

3. Organizational commitment did not mediate the influence of leadership styles on employee performance.

4. Organizational commitment is complete mediation (complete mediation) on the effect learning organization to the employee performance.

5. Excellence and the currency of this research is the research model, there are 3 (three) independent variables of work motivation, leadership style and learning organization, 1 (one) mediating variable is organizational commitment and 1 (one) independent variable is the employee performance, in this case the use of organizational commitment as a mediating variable were lack encountered in previous studies.

\section{Research Contribution}

Theoretical Contributions

1. The findings in this study contribute to the development and confirmation of the theory of organizational commitment and performance in terms of the development of the concept of human resource.

2. The results of this study reinforce the concept of the relation between organizational commitment and employee performance, in addition the study proves that a high level of organizational commitment can improve the high employee performance.

\section{Practical Contributions}

1. The results of this study would provide a positive contribution to the PT. Pelabuhan Indonesia IV (Limited) Branch Bitung to always pay attention, maintain and improve the delivery of work motivation, leadership style and learning organization.

2. The results of this study may provide insight into the importance of the application of the concepts of motivation for employees, leadership styles that exist within a company, learning organization, increased organizational commitment and employee performance in maintaining and developing the human resources in a company.

3. The results of this study reinforce the concept of relationship of work motivation, leadership style and learning organization on organizational commitment and employee performance in previous studies.

\section{Limitations of Research}

1. Respondents involved in this study have the educational background, experience and varied age that not all respondents were able to answer properly, in this case there are respondents who have not been able to answer the questionnaire or convey their ideas well and thus there is a tendency of low response consistency and less in accordance with the actual reality.

2. Measurement of research variables based on the perception of respondents strongly influenced by the respondent memory, judgment to himself, allowing the bias in the measurements.

3. Busyness and time constraints owned by the respondent at the time of filling in the questionnaire or provide feedback were affecting the respondents' answers in describing symptoms or phenomena that occur within the works.

4. The results of research conducted at PT. Pelabuhan Indonesia IV (Limited) Branch Bitung have characteristics that may differ from the other PT. Pelabuhan exist throughout Indonesia, both in ethnic and cultural characteristics.

\section{Conclusions And Recommendations}

\section{Conclusion}

1. Work motivation affects employee performance mediated by the Organizational Commitment. That is, the motivation given PT. Pelabuhan Indonesia IV (Limited) Bitung Branch employees are now fairly and in accordance with the expectations of employees and of course this can improve employee performance. Furthermore, with the high support and mediating organizational commitment of employees of PT. Pelabuhan Indonesia IV (Limited) Branch Bitung, will also further improve their performance towards the achievement of corporate goals.

2. Leadership styles have no effect on employee performance mediated by Organizational Commitment. That is, that the style of leadership in PT. Pelabuhan Indonesia IV (Limited) Branch Bitung currently were less influential in improving the performance of employees, this is due to the style of leadership that is not clear, the leadership styles are always changing depending on the mood and many employees PT. Pelabuhan 
Indonesia IV (Limited) Branch Bitung is less trusting their leaders today. Furthermore, at the present time there are many companies that managed to increase employee performance by implementing transformational and transactional leadership styles, but it is different from the results of this study in which transformational and transactional leadership style had no effect on the performance of employees, meaning that transformational and transactional leadership styles could not be ensure a firm to improve employee performance, because the style of leadership that should be implemented in the company must be strictly in accordance with the circumstances within the company. Then, the leadership style is currently less influential in fostering organizational commitment of employees of PT. Pelabuhan Indonesia IV (Limited) Branch Bitung overall, so this will be an effect on employee performance improvement. If this is left constantly by the management of PT. Pelabuhan Indonesia IV (Limited) Branch Bitung it will have an impact on overall employee performance.

3. Learning organization affects employee performance mediated by the Organizational Commitment. That is, the learning opportunities provided by PT. Pelabuhan Indonesia IV (Limited) Bitung Branch to the employees are now better and can improve overall employee performance.

Furthermore, learning organization with the high support and commitment of the employees of PT Pelabuhan Indonesia IV (Limited) Branch Bitung will further enhance the performance of employees to the achievement of corporate goals.

4. Organizational commitment affects employee performance. That is, the existing Organizational Commitment in PT. Pelabuhan Indonesia IV (Limited) Branch Bitung is now well and can improve overall employee performance.

Thus, the higher organizational commitment of the employees of PT. Pelabuhan Indonesia IV (Limited) Branch Bitung will certainly increase the Employee Performance.

\section{Recommendations}

1. Based on the smallest loading factor on work motivation is an indicator of intrinsic motivation, so it is recommended that PT. Pelabuhan Indonesia IV (Limited) Branch Bitung could always pay attention, maintain and improve the delivery of intrinsic motivation in the form of awards, achievements opportunities and career opportunities that organizational commitment of employees will always be on track and employee performance can be improved more.

2. The overall average value of the leadership style variable were at middle category, it means that the current leadership style were still less influential to enhance employee performance, so it will be good if the management of PT. Pelabuhan Indonesia IV (Limited) Branch Bitung should bring the leadership style according to the situation and the conditions existed currently in the company, should be in accordance with the understanding of employees, company management must have the courage to make changes, so that will foster employee commitment and impact on employee performance improvement at PT . Pelabuhan Indonesia IV (Limited) Branch Bitung.

3. Furthermore, based on the smallest loading factor on learning organization is an indicator of mental models, thus it is recommended that the management of PT. Pelabuhan Indonesia IV (Limited) Branch Bitung have to pay attention, maintain and enhance employee commitment to employee share and togetherness in solving the problem, so that will increase employee organizational commitment and performance as well.

4. Research on organizational commitment as a mediating variable in bridging relationships between work motivation influences, leadership style and learning organization towards the employee performance in a holistic way (as a whole) has not been done. Future studies are expected to explore and in-depth examination particularly about organizational commitment as a mediating variable.

5. The study found that leadership style had no effect on the employee's performance mediated by the organizational commitment, then this could be a reference to further studies that need further research.

6. Other studies could be developed in the future to re-examine the consistency of the results of this study to develop other variables such as organizational culture, ethnic and organizational behavior as a mediating variable.

7. Future studies may examine and develop an understanding of work motivation, leadership style, learning organization, organizational commitment and employee performance at different firms whose different orientation on international coverage.

\section{References}

[1] Adler, N. J. 1997. Organizational Behavior. Third Edition. Cincinnati, Ohio: South-Western College Publishing.

[2] Allen and Meyer. 1991. A Three-Component conceptualization of Organizational Commitment. Human Resources Management Review. The University of Western Ontario. Vol 1 No. 1. pp. 61-69.

[3] Allen and Meyer. 1991. Affective, continuance, and Normative Commitment to the Organizational: An Examination of Construct Validity. Journal of Vocational Behavior. The University Of Western Ontario, Vol. 43. pp. 252-276. 
[4] Aldag, R. and Reschke, W. 1997. Employee Value Added: Measuring Discretionary Effort and Its Value to The Organization. Center for Organization Effectiveness, Inc. 608/833-3332. pp. 1-8.

[5] Argyris, C. 1974. Organizational Learning, Reading, MA: Addison-Wesley.

[6] Armstrong, M., 2003. Reward Management, Fourth Edition. Cogent Page, London.

[7] Aragon, A., 2007. Leadership and Organizational Learning's Role on Innovation and Performance: Lessons from Spain, Journal of Industrial Marketing Management 36 (2007) 349-359.

[8] Barbuto, J. 2005. Full Range Leadership. Nebguide, The Board of Regents of the University of Nebraska on Behalf-Lincoln Extension.

[9] Bass, B. M. 1990. Transformational Leadership: beyond Initiation and Consideration, Journal of management.

[10] Bass, B. M. and Avolio, B. J. 1994. Manual for Improving Organizational Effectiveness Through Transformational Leadership, Sage, Thousand Oaks California.

[11] Bass, B. M. and Avolio, B. J. 1997. The Ethics of Transformational Leadership, Working Papers Academy of Leadership Press. University of Maryland. pp.1-14.

[12] Bass, B. M. And Avolio, B. J. , 2003. Transformational Leadership and Organizational Commitment: Mediating Role of Psychological Empowerment and Moderating Role of Structural Distance, Journal of Organizational Behavior.

[13] Bilik., 2008. Influence of Organizational Commitment, Work Motivation and Leadership Styles on Employee Performance Finance at PT. Krakatau Steel, Diponegoro University Dissertation.

[14] Brymer, R.A., 2011. The Effects of Ethical Leadership on Manager Satisfaction, Commitment, and Beha vioral Outcomes Firm Performances, International Journal of Hospitality Management, 30 (2011) 1020-1026.

[15] Cash and Fischer. 1987. Job Performance and Level of An Appraisal Performance, New York.

[16] Decree of the Minister of Transportation., 2011. HK. 003/1/11, Phb 2011 dated May 6, 2011.Act No. 17 of 2008, Decree of the Ministry of Transportation of Indonesia, Government Regulation No. 56, 57, 58 and 59 in 1991.

[17] Feng, W. C. , 2010. An empirical Study of Performance of University Teachers Based on Organizational Commitment, Job Stress, Health and Achievement Motivation Mental. Canadian Journal of Social Science Vol. No. 6. 4, 2010.

[18] Herzberg, F. 1984. Two-Factor Theory, New York.

[19] Herzberg, F. 1996. The Motivation-Hygiene Theory, Work and the Nature of Man, World Publishing Co.

[20] Herzberg, F., B. Mausner and B. Sniderman. 1959. The Motivation to Work, in Minner John B. 1992, Industrial Organizational Psychology, McGraw-Hill, New York.

[21] Kenny, D. A. , 2011. Learn How you can do a mediation analysis and outputs a text description. http://davidakenny.net/cm/mediate.htm.

[22] Kim, W. G. , 2011. The Effects of Ethical Leadership on Manager Satisfaction, Commitment, and Behavioral Outcomes Firm Performances, International Journal of Hospitality Management, 30 (2011) 1020-1026.

[23] Marquardt. 1994. The Global Learning Organization. Irwin Professional Publishing Burr Ridge, Illinois.

[24] Marquardt. and Michael, J. 1996, Building the Learning Organization: A Systems Approach to Quantum Improvement and Global Success. McGraw Hill, New York.

[25] Mo, S. , 2011. An Exploratory Study Of Intrinsic And extrinsic motivators And Student Performance In An Auditing Course, American Journal of Business Education, ABI/INFORM Research, Feb 2011.

[26] Moon, P. 1993. The Motivation to Work and Work Related Attitudes and Motivation, Industrial Organizational Psychology, New York.

[27] Moon, P. 1994. Appraising Your Staff, Day Wahyudi, Interpreting, Employee Assessment, Management Series No.. 158, New York: Library Binaman Press in PGG-PT

[28] Moralles, V., 2007. Leadership and Organizational Learning's Role on Innovation and Performance: Lessons from Spain, Industrial Marketing Management 36 (2007) 349-359.

[29] Mowday, R. T. Porter, L. W. And Steers, R. M. , 1979. The Measurement of Organizational Commitment. Journal of Vocational Behavior, 14:224-247.

[30] Nawawi, H. 1998. Human Resources Management of Competitive, Gajah Mada University Press, Yogyakarta.

[31] Pedler, B. J. 1991. Learning Company: Project Report Training Agency. New York: McGraw-Hill Maiden Head.

[32] Rifa'i., 2004. The relationship between Leadership Style, Organizational Culture, Achievement Motivation, and Organizational Commitment, the Performance Lecturer at the University of the boarding school in East Java, Dissertation, University of Airlangga

[33] Robbins, S. P. 2002. Principles of Organizational Behavior. Fifth Edition (Translated). Jakarta: publisher.
[34] Robbins, S. P. , 2003. Organizational Behavior. Book 1. Indonesian Edition. Jakarta: PT Publisher. Scholastic Index.

[35] Senge. 1990. The Fifth Discipline: The Art and Practice of the Learning Organization, Doubleday.

[36] Senge. 1994. The Fifth Discipline: The Art and Practice of the Learning Organization, Nicholas Brealey Publishing, London

[37] Sobel, M. E. 1982. Asymptotic confidence intervals for indirect effects in structural equation models. In S. Leinhardt (Ed.), Sociological Methodology 1982 (pp. 290-312). Washington DC: American Sociological Association.

[38] Solimun., 2010. Structural Modeling Multivariate Analysis, Partial Least Square method, First Printing., CV. Image Malang.

[39] Solimun., 2011. Testing for mediation Variable: What Necessary?. International Conference of Basic Science. UB Faculty.

[40] Suprihanto, J. Harsiwi A. and Prakoso H. 2002. Behavior Organizational, First Printing. ISBN 979-8146-73-5. London: School of Economics Publisher Yogyakarta.

[41] Suprihanto, J. 2000. Employee Performance and Development Research, First Edition BPFE, Yogyakarta.

[42] Yukl, A. G. 2002. In Organizational Leadership. Fifth Edition. New Jersey: Prentice Hall. Upper Saddle River, 07458. 